\title{
Динаміка регенеративних процесів у пацієнтів з хронічними ранами при застосуванні PRP-терапіi
}

\author{
С. В. Малик, Я. В. Рибалка, М. В. Безручко, О. С. Осіпов
}

Українська медична стоматологічна академія, м. Полтава

\section{Dynamics of regenerative processes in patients with chronic wounds while application of a prp-therapy}

\author{
S. V. Malyk, Ya. V. Rybalka, M. V. Bezruchko, O. S. Osipov \\ Ukrainian Medical Stomatological Academy, Poltava.
}

\section{Реферат}

Мета. Покращення регенеративних процесів хронічних ран (ХР) шляхом застосування в комлексі лікувальних заходів аутологічної плазми, збагаченої тромбоцитами (АПЗТ) - Plateletrich plasma (PRP).

Матеріали і методи. Проаналізовано результати лікування 200 хворих 3 ХР різного генезу. У пацієнтів 1-ї групи (n=99) комплекс лікування включав PRP-терапію.

Результати. Застосування PRP-терапії приводило до чіткої статистично значущої відмінності $(\mathrm{p}<0,05)$ у швидкості загоєння XР у 1 -й групі порівняно 32 -ю групою, і ця тенденція зберігалась до закінчення лікування. Відносно низьку ефективність PRP-терапії спостерігали у пацієнтів з ХР та хронічною венозною недостатністю (XBH).

Висновки. Використання PRP-терапії в комплексі лікування XP є клінічно ефективним. Застосування цього методу прискорює процеси репарації, скорочує терміни загоєння XР, статистично значущо зменшує площу ранового дефекту.

Ключові слова: планіметрія; хронічні рани; плазма, збагачена тромбоцитами; PRP-терапія.

\section{Abstract}

Objective. Improvement of regenerative processes in chronic wounds (CHW), using complex of treatment measures of autological plasma, plateletrich plasma (PRP).

Materials and methods. Results of treatment of 200 patients, suffering $\mathrm{CHW}$ of various genesis, were analyzed. In patients of the first group $(\mathrm{n}=99)$ complex of treatment have included PRP-therapy.

Results. Application of PRP-therapy have brought to statistically significant difference $(p<0.05)$ in velocity of the CHR healing in the first group, comparing with the second group, and this tendency have had preserved up to the treatment end. In patients with $\mathrm{CHW}$ and chronic venous insufficiency a relatively low efficacy of PRP-therapy was observed.

Conclusion. Application of PRP-therapy in complex of treatment of CHW is clinically effective. Application of this method accelerates the reparation processes, shortens the CHW healing time, reduces the wound defect square statistically significantly.

Keywords: planimetry; chronic wounds; plateletrich plasma; PRP-therapy

Лікування ран є однією з найдавніших хірургічних проблем, яка й до тепер не втратила своєї актуальності. Лікуючи рани, хірурги часто мають справу з дефектами м'яких тканин, для яких властиві ознаки хронічного запалення, висока бактеріальна контамінація, а також переважання дегенеративних процесів над регенеративними. До таких станів відносять рани, що тривало не загоюються, нориці, пролежні.

Незважаючи на широкий перелік лікарських засобів і різні методи для лікування ран шкіри, ХР залишаються суттєвою проблемою [1 - 4].

Застосування АПЗТ, або РRP - це спеціалізована місцева терапія для лікування XP. PRP є частиною плазми, отриманої з аутологічної крові пацієнта, з підвищеним вмістом у ній тромбоцитів, які ініціюють загоєння рани шляхом вивільнення місцевих факторів росту, що виділяють-

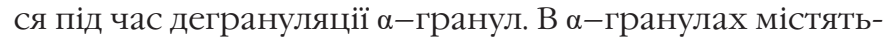
ся секреторні протеїни: тромбоцитарний фактор росту (PDGF), AA-, BB- і AB-ізомери, трансформуючий фактор росту $\beta$ (TGF- $\beta$ ), тромбоцитарний фактор 4 (PF4), ін- терлейкін-1 (IL-1), тромбоцитарний фактор ангіогенезу (PDAF), судинний ендотеліальний фактор (VEGF), епідермальний фактор росту (EGF), тромбоцитарний ендотеліальний фактор росту (PDEGF), епітеліально-клітинний фактор росту (ОУФТ), інсуліноподібний фактор росту (IФP), остеокальцин (Ос), остеонектин (О), фібриноген (Fg), вітронектин (Vn), фібронектин (Fn), тромбоспондин-1 (TSP-1). Усі вони сприяють залученню недиференційованих клітин у знов сформований матрикс і запуску клітинного ділення. Також РRP пригнічуе вивільнення цитокінів і обмежує процес запалення, тим самим покращуючи загоєння [5 - 7].

Опубліковані експериментальні та клінічні дані [8 - 10] свідчать про позитивний вплив PRP на стимуляцію ангіогенезу тканин та загоєння ран, що у свою чергу дає підстави припустити, що застосування методики PRP у пацієнтів з ХР є ефективним та перспективним.

Мета дослідження: покращення регенеративних процесів ХР шляхом застосування в комлексі лікувальних заходів PRP-терапіі. 


\section{Матеріали і методи дослідження}

У період з 2011 по 2017 р. на базі хірургічного відділення № 1 Міської клінічної лікарні м. Полтави проведено комплексне обстеження і лікування за запропонованою та обгрунтованою методикою 99 хворих із ХР (1-ша група). Пацієнти цієї групи додатково до комплексного лікування ХР отримували місцеве лікування стимуляторами регенеративного процесу - PRP з подальшим виконанням, за необхідності, вільної аутодермопластики розщепленим клаптем. За стандартними підходами лікували 101 пацієнта з ХР (2-га група).

Пацієнти 1-ї групи мали неоднорідний за етіологією рановий процес. Тому в $1-$ й групі виділено три підгрупи: $1 \mathrm{~A}-44$ (45\%) хворих 3 трофічними виразками та хронічною артеріальною недостатністю (ХАН); 1B - 30 (30\%) хворих з трофічними виразками та ХBН; 1C - 25 (25\%) хворих, які мали ХР іншої етіології.

Для аналізу отриманих результатів аналогічно з 1-ю групою у 2-й групі виділено три підгрупи: 2А - 42 (42\%) пацієнти з трофічними виразками та ХАН; 2B - 31 (31\%) пацієнт з трофічними виразками та ХВН; 2C - 28 (27\%) пацієнтів, які мали ХР іншої етіології.

Обидві групи порівнянні за віком, статтю, тяжкістю загального стану, характером супутньої патології.

Тривалість ранового процесу у хворих 1-ї групи корелювала з тривалістю ранового процесу у пацієнтів 2-і групи та становила від 6 тиж до 6 міс. Усі хворі досліджуваних груп на догоспітальному етапі були консультовані ангіохірургом, отримували амбулаторне лікування у хірурга за місцем медичного обслуговування, а у разі довготривалого ранового анамнезу - курси лікування в умовах загального хірургічного стаціонару.

Усім хворим з трофічними виразками та ХВН застосовували компресію еластичним трикотажем, призначали флеботоніки, системні флебопротектори. Лікування па- цієнтів підгруп 1А та 2А з цукровим діабетом включало функціональне розвантаження, корекцію гіперглікемії, а також наявних нейро- та ангіопатичних порушень згідно з існуючими рекомендаціями.

Усім пацієнтам обох груп проводили місцеве лікування ХР стандартним способом, що включав хірургічну обробку гнійного вогнища, під час якої видаляли некротизовані тканини, по можливості радикально видаляли наявний струп і нашарування фібрину, які нерідко покривали грануляційну тканину. Надалі для очищення поверхні рани місцево використовували різні антисептики, в тому числі розчини декасану, хлоргексидину, 3\% розчин перекису водню, 0,1\% розчин перманганату калію, 1\% розчин диоксидину, ними зрошували поверхню рани під час оперативного втручання або щоденних перев'язок. Потім накладали марлеву асептичну пов'язку з 0,1\% розчином йодопірину або мазевими засобами на водорозчинній основі (левосин, левомеколь).

Усім пацієнтам призначали антибактеріальну терапію з 1-го дня госпіталізації відповідно до загальноприйнятих схем.

Хворим 1-ї групи застосовували РRP у вигляді щоденних підшкірних та внутрішньошкірних ін'єкцій та аплікацій, яку отримували за методикою J. Chukrun шляхом центрифугування [5]. Утворену плазму набирали в два інсулінових шприци по 1 мл кожен і вводили по периферії рани (близько 20 ін'єкцій по 0,1 мл). Частину плазми, що залишилася, у вигляді аплікації накладали на рановий дефект і закривали сухою серветкою на 24 год.

Для дослідження та об'єктивізації процесів загоєння ХР у пацієнтів обох груп визначали площу ранових дефектів із застосуванням програми «LesionMeter» для операційної системи Android, яка встановлена на смартфон. Для вимірювання площі поверхні ХР за допомогою даної програми фотографували сегмент кінцівки з рановим

\begin{tabular}{|c|c|c|c|c|c|c|c|c|c|c|c|c|}
\hline \multirow{5}{*}{$\begin{array}{c}\text { Площа ранового } \\
\text { дефекту }\end{array}$} & \multicolumn{12}{|c|}{ Групи } \\
\hline & \multicolumn{6}{|c|}{ 1-ша } & \multicolumn{6}{|c|}{ 2-га } \\
\hline & \multicolumn{6}{|c|}{ підгрупи } & \multicolumn{6}{|c|}{ підгрупи } \\
\hline & \multicolumn{2}{|c|}{$1 \mathrm{~A}$} & \multicolumn{2}{|c|}{$1 \mathrm{~B}$} & \multicolumn{2}{|c|}{$1 \mathrm{C}$} & \multicolumn{2}{|c|}{$2 A$} & \multicolumn{2}{|c|}{$2 \mathrm{~B}$} & \multicolumn{2}{|c|}{$2 C$} \\
\hline & абс. & $\%$ & абс. & $\%$ & абс. & $\%$ & абс. & $\%$ & абс. & $\%$ & абс. & $\%$ \\
\hline Менше $10 \mathrm{~cm}^{2}$ & 8 & 18,2 & 5 & 16,7 & 5 & 20 & 9 & 21,4 & 6 & 19,4 & 7 & 25 \\
\hline $11-26 \mathrm{~cm}^{2}$ & 21 & 47,7 & 19 & 63,3 & 10 & 40 & 20 & 47,6 & 20 & 64,5 & 10 & 28 \\
\hline $27-50 \mathrm{~cm}^{2}$ & 12 & 27,3 & 5 & 16,7 & 5 & 20 & 11 & 26,2 & 4 & 12,9 & 8 & 28,6 \\
\hline Більше 50 см² & 3 & 6,8 & 1 & 3,3 & 5 & 20 & 2 & 4,8 & 1 & 3,2 & 3 & 10,7 \\
\hline
\end{tabular}

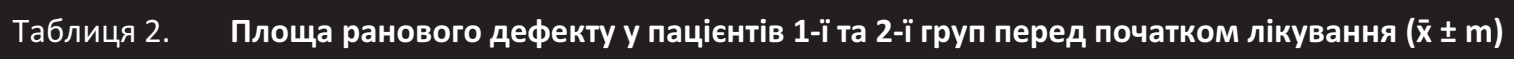

\begin{tabular}{|c|c|c|c|c|c|c|}
\hline \multirow{4}{*}{$\begin{array}{c}\text { Площа ранового } \\
\text { дефекту }\end{array}$} & \multicolumn{6}{|c|}{ Групи } \\
\hline & \multicolumn{3}{|c|}{ 1-ша } & \multicolumn{3}{|c|}{ 2-га } \\
\hline & \multicolumn{3}{|c|}{ підгрупи } & \multicolumn{3}{|c|}{ підгрупи } \\
\hline & $1 \mathrm{~A}$ & $1 \mathrm{~B}$ & $1 \mathrm{C}$ & $2 A$ & $2 B$ & $2 C$ \\
\hline Менше 10 см² & $7,4 \pm 0,6$ & $6,9 \pm 0,8$ & $7,6 \pm 0,7$ & $6,5 \pm 0,4$ & $7,1 \pm 0,8$ & $8,1 \pm 0,6$ \\
\hline $11-26 \mathrm{~cm}^{2}$ & $20,5 \pm 1,3$ & $22,9 \pm 1,2$ & $24,7 \pm 1,5$ & $19,8 \pm 1,6$ & $24,2 \pm 2,9$ & $21,7 \pm 1,5$ \\
\hline $27-50 \mathrm{~cm} 2$ & $44,5 \pm 2,7$ & $39,7 \pm 3,4$ & $41,4 \pm 3,6$ & $38,3 \pm 2,9$ & $41,2 \pm 3,7$ & $37,8 \pm 4,3$ \\
\hline Більше 50 см² & $73,3 \pm 9,7$ & $79,1 \pm 11,3$ & $89,7 \pm 24,8$ & $76,2 \pm 10,3$ & $74,5 \pm 8,7$ & $80,4 \pm 12,9$ \\
\hline
\end{tabular}


Таблиця 3. Динаміка загоєння ХР у пацієнтів 1-ї та 2-ї груп ( $\overline{\mathbf{x}} \pm \mathbf{m})$

\begin{tabular}{|c|c|c|c|c|c|c|}
\hline \multirow{4}{*}{ Етапи спостереження } & \multicolumn{6}{|c|}{ Групи } \\
\hline & \multicolumn{3}{|c|}{ 1-ша } & \multicolumn{3}{|c|}{ 2-га } \\
\hline & \multicolumn{3}{|c|}{ підгрупи } & \multicolumn{3}{|c|}{ підгрупи } \\
\hline & $1 \mathrm{~A}$ & $1 \mathrm{~B}$ & $1 \mathrm{C}$ & $2 \mathrm{~A}$ & $2 \mathrm{~B}$ & $2 \mathrm{C}$ \\
\hline До лікування & $36,4 \pm 4,2$ & $34,6 \pm 5,4$ & $38,8 \pm 7,6$ & $38,3 \pm 5,1$ & $30,9 \pm 4,7$ & $36,1 \pm 9,3$ \\
\hline \multicolumn{7}{|l|}{ Період лікування, доба } \\
\hline 4-та & $33,7 \pm 4,1$ & $33,2 \pm 4,7$ & $32,4 \pm 5,1$ & $37,9 \pm 4,8$ & $30,3 \pm 4,6$ & $35,9 \pm 4,2$ \\
\hline 8-ма & $25,6 \pm 4,4$ & $29,5 \pm 4,2$ & $23,3 \pm 3,9 *$ & $33,5 \pm 5,3$ & $28,9 \pm 4,2$ & $33,7 \pm 4,1$ \\
\hline 12-та & $18,2 \pm 3,8^{*}$ & $26,3 \pm 3,7$ & $16,2 \pm 4,1^{*}$ & $29,8 \pm 4,3$ & $26,5 \pm 4,3$ & $29,6 \pm 4,3$ \\
\hline 16-та & $12,8 \pm 3,2^{*}$ & $21,5 \pm 3,6$ & $10,3 \pm 3,9 *$ & $23,9 \pm 4,4$ & $24,7 \pm 3,9$ & $22,5 \pm 4,6$ \\
\hline 20-та & $7,5 \pm 3,4^{*}$ & $17,5 \pm 3,9$ & $5,1 \pm 3,7^{*}$ & $17,8 \pm 3,8$ & $19,3 \pm 4,2$ & $15,8 \pm 3,8$ \\
\hline Закінчення лікування & $4,3 \pm 3,5^{*}$ & $11,7 \pm 3,7$ & $3,4 \pm 1,9^{*}$ & $14,2 \pm 3,4$ & $15,3 \pm 3,9$ & $11,3 \pm 3,2$ \\
\hline
\end{tabular}

\section{Таблиця 4. Оцінка ефективності лікування пацієнтів досліджуваних груп}

\begin{tabular}{|c|c|c|c|c|c|c|c|c|c|c|c|c|}
\hline \multirow{5}{*}{ Критерії оцінки } & \multicolumn{12}{|c|}{ Групи } \\
\hline & \multicolumn{6}{|c|}{ 1-ша } & \multicolumn{6}{|c|}{ 2-га } \\
\hline & \multicolumn{6}{|c|}{ підгрупи } & \multicolumn{6}{|c|}{ підгрупи } \\
\hline & \multicolumn{2}{|c|}{$1 \mathrm{~A}$} & \multicolumn{2}{|c|}{ 1B } & \multicolumn{2}{|c|}{$1 C$} & \multicolumn{2}{|c|}{$2 \mathrm{~A}$} & \multicolumn{2}{|c|}{$2 B$} & \multicolumn{2}{|c|}{$2 C$} \\
\hline & абс. & $\%$ & абс. & $\%$ & абс. & $\%$ & абс. & $\%$ & абс. & $\%$ & абс. & $\%$ \\
\hline «a» & 23 & 52,3 & 5 & 16,7 & 14 & 56,0 & 10 & 23,8 & 3 & 9,7 & 7 & 25,0 \\
\hline «B» & 13 & 29,5 & 8 & 26,6 & 7 & 28,0 & 15 & 35,7 & 8 & 25,8 & 8 & 28,6 \\
\hline «C» & 5 & 11,4 & 12 & 40,0 & 3 & 12 & 10 & 23,8 & 14 & 45,1 & 9 & 32,1 \\
\hline «d» & 3 & 6,8 & 5 & 16,7 & 1 & 4,0 & 5 & 11,9 & 4 & 12,9 & 3 & 10,7 \\
\hline «e» & - & - & - & - & - & - & 2 & 4,8 & 2 & 6,5 & 1 & 3,6 \\
\hline
\end{tabular}

дефектом, біля якого розміщували еталон масштабування у вигляді стандартної банківської пластикової картки, після цього на отриманому фото за допомогою курсора по периметру обводили рановий дефект та автоматично отримували його площу в см² $^{2}$. Отриманий результат заносили в архів програми.

Площу початкового ранового дефекту визначали під час госпіталізації пацієнта в стаціонар до початку лікування та в період лікування для визначення динаміки загоєння рани на 4, 8, 12, 16-ту і 20-ту добу, а також на етапі закінчення лікування.

Залежно від розмірів ранового дефекту ХР поділяли на малі - площею до $10 \mathrm{~cm}^{2}$, середніх розмірів - $11-26 \mathrm{~cm}^{2}$, великі - 27 - $50 \mathrm{~cm}^{2}$ та обширні - більше $50 \mathrm{~cm}^{2}$. Структура пацієнтів обох груп залежно від площі ранового дефекту була порівнянною (табл. 1).

У пацієнтів обох груп превалювали ранові дефекти середніх розмірів (площею $11-26 \mathrm{~cm}^{2}$ ). Досить вагому частку в обох групах складали пацієнти з великими та обшир-

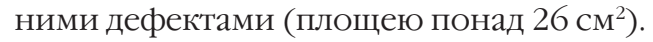

\section{Результати}

Перед початком лікування в усіх підгрупах 1-ї та 2-ї груп середні значення площі ранового дефекту були порівнянні (табл. 2).

У підгрупі 1А та підгрупі 2А площа ранового дефекту становила у середньому $(36,4 \pm 4,2)$ та $(38,3 \pm 5,1)$ см $^{2}$ відповідно, що не мало статистично достовірної різниці (р $>0,05)$. У підгрупі 1В площа трофічної виразки становила в середньому $(34,6 \pm 5,4) \mathrm{cm}^{2}$, а в підгрупі $2 \mathrm{~B}-(30,9 \pm 4,7) \mathrm{cm}^{2}$, що також не мало статистично достовірної різниці (p >
0,05). У підгрупі 1С та підгрупі 2С середня площа ранового

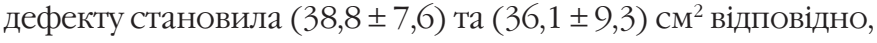
тобто не було статистично достовірної різниці ( $>$ > 0,05).

Загальна динаміка зменшення площі ранового дефекту ( мабл.3) у пацієнтів з ХР та ХАН підгрупи 1А перші 8 діб лікування статистично значущої різниці порівняно з пацієнтами підгрупи 2А не мала ( $>$ > 0,05). Однак після 12-ї доби комплексного лікування у пацієнтів підгрупи 1А відмічено чітку статистично значущу відмінність ( $<<0,05)$ у швидкості загоєння ХР порівняно з підгрупою 2А, і ця тенденція зберігалась до закінчення лікування.

У пацієнтів підгрупи 1В з трофічними виразками та ХВН також відмічено більш швидке зменшення площі ранового дефекту порівняно з пацієнтами підгрупи 2В, однак статистично значущої відмінності протягом усього періоду стаціонарного лікування не спостерігали (р > 0,05).

При порівнянні динаміки зменшення площі ранового дефекту у пацієнтів з ХР іншої етіології підгруп 1С та 2C встановлено статистично значущу відмінність $(\mathrm{p}<0,05)$ між середніми розмірами площі дефектів уже на 8-му добу стаціонарного лікування.

Основним критерієм оцінки результатів лікування був ступінь зменшення площі ранового дефекту: «а» - повне загоєння рани; «в» - зменшення площі рани на 70\% і більше ії початкової площі; «с» - зменшення площі рани на 50 - 69\%; «d» - зменшення площі рани на 30 - 49\%; «е» - відсутність ознак регенерації або зменшення трофічної виразки менше ніж на 30\%.

Добрим результатом лікування вважали критерії «а» та «в», задовільним - критерій «с», незадовільними - критеpiï «d» та «e». 


\section{Обговорення}

Відповідно до табл. 4 у підгрупі 1А 1-ї групи добрий результат лікування отримано у 36 (81,8\%) пацієнтів, у підгрупі 2А - лише у 25 (56,6\%) пацієнтів. Зменшення площі ранового дефекту на 49\% або менше в підгрупі 1А було лише у 3 (6,8\%) пацієнтів, у підгрупі 2А - у 7 (16,7\%). Добрий результат лікування відмічено у 13 (43,3\%) хворих підгрупи 1В та у 11 (35,5\%) хворих підгрупи 2B; незадовільні результати констатовано у 5 (16,7\%) та 6 (19,4\%) пацієнтів відповідно. У підгрупі 1С повне загоєння ХР або зменшення їх площі на 70\% і білыше встановлено у 21 (84\%) пацієнта, а у підгрупі 2С - лише у 15 (53,6\%) пацієнтів. Незадовільні результати в цих підгрупах констатовано у 1 (4\%) та у 4 (14,3\%) хворих відповідно.

\section{Висновки}

1. Дослідження планіметричних показників загоєння ХР у пацієнтів 1-ї групи, яким загальноприйняті лікувальні заходи доповнювали місцевим застосуванням PRP, показало, що площа ранових дефектів у підгрупах 1А та 1C статистично значущо зменшувалася на 8-му та 12-ту добу відповідно порівняно з підгрупами 2А та 2С, однак у пацієнтів підгрупи 1В суттєвої відмінності з підгрупою 2В у процесах репарації ХР встановлено не було. В результаті оцінки ефективності лікування кращі показники отримано також у пацієнтів підгруп 1А та 1C: повне загоєння рани або зменшення іiі площі на 70\% і більше констатовано у 81,8 та 84\% пацієнтів відповідно. У 2-й групі повного або значного загоєння ХР вдалося досягти лише у 56,6\% пацієнтів підгрупи 2А та у 53,6\% - підгрупи 2С. У свою чергу у пацієнтів з ХР та ХВН ефективність лікування залишилася низькою та становила 43,3 - у підгрупі 1В та 35,5\% - у підгрупі 2B.

2. Використання PRP-терапії в комплексі лікування XP $€$ клінічно ефективним. Застосований метод сприяв прискоренню процесів репарації ран, зменшенню термінів загоєння ХР, статистично значущому зменшенню площі ранового дефекту.

\section{References}

1. Abaev JuK. Rasstrojstvo, zazhivlenija ran i metody ih korrekcii. Vestnik hirurgii. 2005;164(1):111-3. [In Russian].

2. Bok ILi, Barton LG. Hirurgicheskoe lechenie kozhnyh i prolezhnevyh jazv. Moskva: Medicina; 2003. 320 s. [In Russian].

3. Duzhyi ID, Kysliakov VP, Popadynets VM, et al. Do problemy likuvannia trofichnykh vyrazok nyzhnikh kintsivok. Kharkivska khirurhichna shkola. 2017;82(1):96-9. [In Ukrainian].

4. Obolenskij VN. Troficheskie jazvy nizhnih konechnostej, obzor problemy RMZh. 2010;(4):28-35. [In Russian].

5. Ahmerov R, Zarudij R, Rychkova I. Plazmolifting (Plasmolifting) lechenie vozrastnoj atrofii kozhi, bogatoj trombocitami autoplazmoj. Jesteticheskaja medicina. 2011;10(2):3-9. [In Russian].

6. Frechette J, Martineau I, Gagnon G. Platelet rich plasma: growth factor content and roles in wound healing. J. Dent. Res. 2005;84(5):434-9.

7. Pietramaggiori G. Freeze-dried platelet-rich plasma shows beneficial healing properties in chronic wounds. Wound Repair Regen. 2006;14(5):573-80.

8. Obolenskij VN, Ermolova DA. Primenenie trombocitarnyh faktorov rosta i kollagenovyh biopreparatov $\mathrm{v}$ lechenii bol'nyh s hronicheskimi troficheskimi jazvami razlichnoj jetiologii. Hirurgija. 2012;(5):42-6. [In Russian].

9. Lyhman VN, Arsenij II, Mardanjan KR, et al. Opyt primenenija autoplazmy obogashhennoj trombocitami dlja stimuljacii reparativnyh processov u bol'nyh s troficheskimi jazvami venoznoj jetiologii. Harkovs'kaja hirurgicheskaja shkola. 2017; 83 (2):159-61 [in Russian].

10. Mehta S, Orthop J, Watson JT. Platelet rich concentrate: basic science and current clinical applications. Trauma. 2008;22(6):432. 